\title{
Effect of Strategic Leadership on Organizational Performance of Family Owned Businesses in Nakuru East Sub County, Kenya
}

\author{
Violah Jepkemboi Ronoh, John Kipkorir Tanui
}

\begin{abstract}
Family owned businesses play a crucial role in the economy through employment creation, income generation and also in accumulation of wealth. However, the family owned businesses face performance challenges such as poor employee performance leading to low profit margins or losses, employee payment challenges and marketing challenges. The study seeks to examine the effect of strategic leadership on performance of family owned businesses in Nakuru East Sub County, Kenya. The objectives of the study included; To examine the effect of organizational culture on the performance of family owned businesses in Nakuru East Sub County, Kenya, and To assess the effect of corporate governance on the performance of family owned businesses in Nakuru East Sub County, Kenya. The study used descriptive research design and target businesses owned by families within Nakuru East Sub County. The study targeted the population of 2,600 family businesses operating within Nakuru East Sub County. The study used stratified random sampling to arrive at the sample size desired in the study. The sample size was 96 respondents. From the findings the study concluded that organizational culture had a statistically significant positive correlation with business performance. In addition the study concluded that there was a statistically significant positive correlational relationship between corporate governance and business performance. From the conclusion the study recommended that resources management should be emphasized on in order to lead to improved business performance of the family businesses. The study thus recommended that the aspects should be emphasized on by the management.
\end{abstract}

Index Terms - Corporate Governance, Family Owned Businesses, Organizational Culture, Performance, Strategic Leadership.

\section{INTRODUCTION}

According to Mohamed and Gichinga (2018) competitive strategies refers to the distinctive approach that a Strategic leadership refers to the ability of businesses management team to communicate the strategic vision of the businesses or certain department in a business and inspire others to have the same vision. Strategic leadership relates to organizational culture, corporate governance, resources management and strategic direction(Xi, Kraus, Filser, \&Kellermanns, 2013). Organizational culture refers to the values, beliefs and way of interacting in an organization that portrays a unique psychological working environment in an organization.

Violah Jepkemboi Ronoh, Kabarak University, Kenya

John Kipkorir Tanui, Kabarak University, Kenya
Corporate governance refers to a system of rules, practices, policies and guidelines that control the operations of an organization.

Family owned businesses may start as a micro enterprise and grow into small businesses, medium-sized and gradually to large businesses. Family owned businesses play a crucial role in the economy through employment creation, income generation and also in accumulation of wealth. In the United States of America, family owned businesses contribute to $90 \%$ of all the businesses in America. It is estimated that between $70 \%$ and $80 \%$ of the businesses in Kenya are owned by families. According to Institute for Family Businesses (IFFB), (2018), 60\% of the employed Kenyans are employed in family owned businesses. However, only $30 \%$ of the family owned businesses survive to the second generation, $12 \%$ survive to the third generation and $3 \%$ to the fourth generation in the businesses succession chain(Bizri, 2016).

Family owned businesses face performance challenges in diverse ways. Most of the family owned businesses are unable to survive competition effectively and therefore lack competitive advantage among its competitors. Family owned businesses also more time than not fail to satisfy customer demands on time. Other performance challenges of family owned businesses included poor employee performance leading to low profit margins or loss. Most of these businesses are unable to pay their employees on time leading to high employee turnover. Family owned businesses have been also associated to poor performance in regard to inability to increase both physical businesses operation premises and also inability to increase its target market as well as its resources(Bannò\&Sgobbi, 2016).

In Indonesia, Sengke (2016)found out that the type of leadership affected the performance of family businesses. It was established that most of the family owned businesses were run on dictatorship and the successor of the businesses was determined through preferential treatment and not on merit of competence. The family biasness successor enjoyed full authority and freedom to run all the family businesses. It was concluded that good family relationships and participative leadership promoted the growth of the family businesses to a large extent.

In Nigeria, Palladan, Abdulkadir and Chong (2016)established that family owned businesses faced diverse leadership and performance challenges. Lack of proper policies and programmes to control the family businesses resulted to low income for the businesses as well as low profitability of the businesses ventures owned by family 
members. Experience of the manager of the family owned businesses was also attributable to the performance metrics of the businesses.

M'Ithiria and Musyoki (2014)found out that governance structures in family owned micro and small businesses in Nairobi County affected the growth of the businesses. In this regard, the ability of the leadership structure to open room for faster decision and also provide important information affected the growth of businesses. Policies regarding trade secrets, businesses performance information communication, formulation of new strategies and policies in respect to sharing of profits from the businesses among the family members were also found to affect the level of performance of family owned businesses. The leadership style of person running the family businesses as well as planning for family businesses succession were also found to affect the performance of the businesses.

The study was carried out in Nakuru East Sub County and involved family owned businesses. Nakuru East Sub County is considered as one of the best places to invest in Kenya due to the endless businesses opportunities. It is the headquarters of Nakuru County and attracts investors from all over the country as well as foreign countries. Businesses people have taken advantage of the high population, good transport network, security, affordable housing and cheap labour to run a successful business in Nakuru East Sub County.

\section{A. Statement of the Problem}

Between $70 \%$ to $80 \%$ of the businesses in Kenya are family owned businesses and $60 \%$ of the employed Kenyans work in family owned businesses, failure to solve the performance problems facing family owned businesses in Kenya would result to economic challenges in the country and high poverty levels in families (Institute for Family Businesses, 2018). Strategic leadership aspects such as organizational culture, corporate governance, resources management and strategic direction may be key determinates of performance of family owned businesses. Poor strategic leadership such as failure to adhere to the set core values and beliefs in a businesses, poor governance strictures, poor resource management and unclear strategic direction of the businesses may lead to low profitability (Bannò\&Sgobbi, 2016).

Some studies have been conducted in an attempt to find a solution for the different performance challenges of family owned businesses in diverse contexts. (Agbim\&Ph, 2018)found out that family businesses faced leadership challenges that resulted to poor performance if the family owned businesses. Agbim and Ph (2018) established that family owned businesses in Nigeria faced diverse leadership and performance challenges. These studies were done in different contexts and therefore a contextual research gap to be filled by the current study. It is therefore on this background that the current study seeks to establish the influence of organizational culture, corporate governance, resources management and strategic direction on performance of family owned businesses in Nakuru East Sub County, Kenya.

\section{B. Objectives of the Study}

i. To examine the effect of organizational culture on the performance of family owned businesses in Nakuru East Sub County, Kenya

ii. To assess the effect of corporate governance on the performance of family owned businesses in Nakuru East Sub County, Kenya

\section{Research Hypotheses}

$\mathbf{H}_{01}$ : Organizational culture has no significant statistical influence on the performance of family owned businesses in Nakuru East Sub County, Kenya

$\mathbf{H}_{\mathbf{0 2}}$ : Corporate governance has no significant statistical influence on the performance of family owned businesses in Nakuru East Sub County, Kenya

\section{LITERATURE REVIEW}

The paper was based on Resource Based Advantage which was conceptualized by Jay Barney in 1991 through publication of an article "Firm Resources and Sustained Competitive Advantage" (Emeagwal\&Ogbonmwan, 2018). The theory places the availability of resources as a means of sustainable competitive advantage for the firms. The presence of resources enables the firm to create competitive advantage for the firm. The resources can either tangible or intangible resources for the firm. The tangible resources are those resources that can be touched including buildings and equipment while the intangible resources can't be touched including patents and rare skills (Hart \& Dowell, 2010). The study utilized the resource-based theory for the purposes of the explaining the role of resources management on the performance of family owned business. The presence of positive organizational culture and corporate governance can be considered as organizational resources for the firm which can be used to improve on the performance of family owned business in Nakuru East Sub County, Kenya.

\section{A. Organization culture and performance of businesses}

In the United Kingdom, Sadighi (2017) investigated the role of organizational culture on the performance of Small and Medium-Sized Enterprises (SMEs) in the health sector. Organization culture aspects that the study investigated included clan culture, adhocracy culture, hierarchy culture and market culture. Using structured questionnaires, the study revealed that there was a positive and significant relationship between clan culture, adhocracy culture, hierarchy culture, market culture and performance of the SMEs selected for the study. Using regression analysis, the study also revealed that organizational culture significantly predicts the level of organizational performance. In respect to this, market culture had the highest influence on organizational performance. In line to this finding, Larentis, Simone, and Antonio (2017) indicated that market culture was a significant predictor of organizational performance in organizations in Brazil.

Leithy (2017) carried out a study that sought to investigate the 
relationship between organizational culture and organizational performance of organizations in China. The study adopted descriptive research study and collected data by use of questionnaires. It was revealed that there was a positive relationship between the organizational culture and organizational performance of organizations sampled in the study. However, these findings are not consistent with those by Aliyu and Rosli (2014) on the influence of organizational culture on performance of SMEs in Nigeria. Aliyu and Rosli (2014) established that there was a negative relationship between organizational culture and performance of SMEs in Nigeria. The study recommended proper structuring of organizational beliefs and practices in order to improve the performance level of the SMEs in Nigeria.

In a study that involved 80 banks in Pakistan, Latif (2016) sought to investigate the influence of organizational culture on performance of banks. A sample of 341 respondents was used in this study whose data collection was through the administration of questionnaires. Latif (2016) found out that there was a positive and significant relationship between collaborative culture and performance of commercial banks in Pakistan. The study recommended team work in execution of duties within the banks in order to improve collaboration between employees and hence higher levels of performance for the banks. Saad and Abbas (2018) concurs with the finding by establishing that organizational culture aspect such as change management, and teamwork were positively related to performance of Arabian public sector firms

\section{B. Corporate governance and performance of businesses}

The leadership structure of an organization has been evaluated in by different scholars in respect to its influence of the performance of organization. Quang, Kim, \& Yi (2015) carried out a study in Vietnam to establish the influence of corporate governance on the performance of private sector businesses. The study was based on descriptive survey research design and collected its data through the use of closed ended questionnaires. Using regression analysis, it was revealed that corporate governance affected the level of performance of the private businesses in terms of profits before tax, contribution to state budget, and in terms of return on asset. These concurs with a study conducted by $\mathrm{Li}$, Armstrong and Clarke (2014) in Islamic banks in Australia. The study noted that there was a significant influence of corporate governance on the performance of Islamic banks in Australia.

In a study to examine the role of corporate governance on financial performance of businesses in Indonesia, Naimah and Hamidah (2017) focused on the role of board size and board independence, audit committee meeting, audit committee size, outside directors and corporate governance perception index. The study used correlation research design and gathered its data using both primary methods (questionnaires) and secondary methods (financial reports). Naimah and Hamidah(2017) established that there was significant relationship between the corporate governance and financial performance of the businesses. Using regression analysis, it was established that board size and board independence, audit committee meeting, audit committee size, outside directors and corporate governance perception index significantly predicted the financial performance of businesses in Indonesia.

Homaidi, Almaqtariand Ahmad (2019) carried out a study that sought to establish the influence of corporate governance on the financial performance of hotels in India. Corporate governance was conceptualized in terms of board size, audit committee size,board competencies, and institutional ownership while financial performance was measured in terms of return on assets. Using regression analysis, the study established that there was a significant impact on financial performance of hotels due to corporate governance mechanism such as board size, audit committee size, board competencies, and institutional ownership. These results are comparable to the findings of (Kulathunga, Weerasinghe, \&Jayarathne, 2017)corporate governance mechanism used has significant impact of the financial performance of large corporation in the two countries. It was revealed in this respect that good corporate governance increased the returns of the organizations under investigation.

Based on a meta-analysis, a study by M'Ithiria and Musyoki (2014) sought to establish the influence of corporate governance on the performance of organizations in Kenya context. The study found out that most of studies carried out in Kenyan context has establish a link between corporate governance and performance of Kenya organizations. Similarly, in Rwandan context, Ndemezo and Kayitana (2018), established that corporate governance aspect such as managers experience, leadership styles and mangers education affected the level of performance of organizations in terms of return on assets and market share.

\section{Research Gaps}

The literature reviewed in this study indicates research gaps that the current study seeks to fill. In the context of organizational culture, Sengke (2016) carried out a study that sought to investigate the influence of on the performance of businesses in Indonesia. On the same context, Sadighi (2017) investigated the role of organizational culture on the performance of Small and Medium-Sized Enterprises (SMEs) in the health sector in the United Kingdom. Since these studies involved organizations that operated in different businesses environment from the organizations in Kenya. Therefore could not be comparable to Kenya organizations and therefore the need to fill this contextual research gaps by carrying out a study in Kenyan context.A study by Leithy (2017) that sought to investigate the relationship between organizational culture and organizational performance of organizations in China and a study by Aliyu and Rosli (2014) that sought to establish the relationship between organizational culture and performance of SMEs in Nigeria presents a conceptual research gap since they only focused on one element of organizational culture. The current study filled this gap by carrying out a study that involves several organizational culture aspects such as entrepreneurial culture, consensual culture, bureaucratic culture and competitive culture. 


\section{Conceptual Framework}

Inldependent Varialle

Depentenlt Tawialle

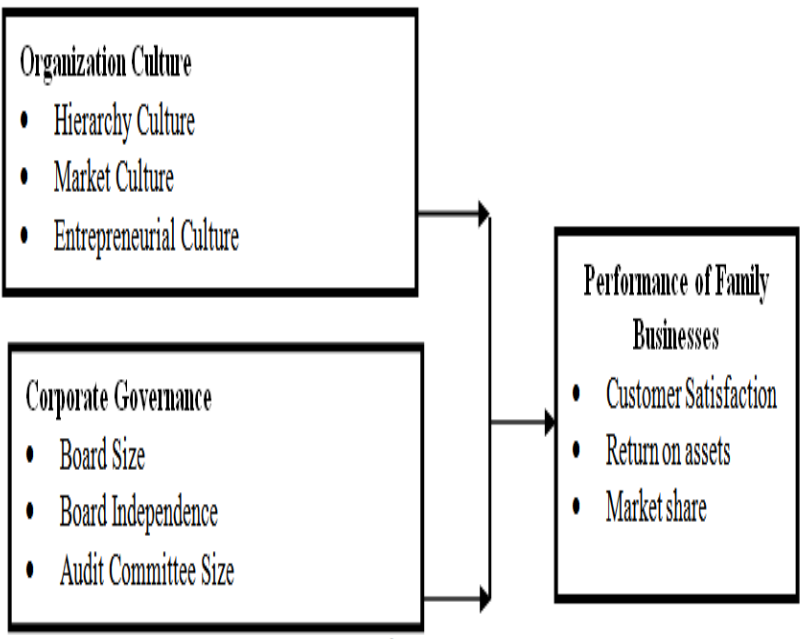

\section{METHODOLOGY}

The study adopted descriptive research design. This refers to the research design whereby data is collected from the natural setting of the phenomenon under investigation(Nicholson, 2011). The study was carried out in Nakuru East Sub County and involved family owned businesses. Nakuru East Sub County is considered as one of the best places to invest in Kenya due to the endless businesses opportunities. The study targeted businesses owned by families within Nakuru East Sub County. According to the Licensing Department at the County Government of Nakuru in 2019, there are a varied population of 2600 family businesses operating within Nakuru East Sub County. This formed the unit of observation. From the 2600 family-owned businesses, the study targeted the businesses managers/owners. This implies that the target population of the study was 2600 owner. The sample size for the study was determined using the Nassiuma formula for sample size termination. The formula and computation is as follows;

$\mathrm{n}=\left(\mathrm{NC}^{\wedge} 2\right) /\left(\mathrm{C}^{\wedge} 2+(\mathrm{N}-1) \mathrm{e}^{\wedge} 2\right)$

Where;

$\mathrm{n}=$ Sample size,

$\mathrm{N}=$ Population size,

$\mathrm{C}=$ Coefficient of variation $=0.5$

$\varepsilon=$ Standard margin of error $=0.05$

On computing;

$\mathrm{n}=(2600 * \llbracket(0.5) \wedge 2) /\left(\left[\begin{array}{ll}(0.5) \wedge 2+(2600-1) \llbracket(0.05 \rrbracket \wedge 2\end{array}\right)=\right.$ 96 respondents

The sample size is therefore 96 respondents.

The study further used stratified random sampling to arrive at the sample size desired in the study. Stratified random sampling was used due to differences of businesses sector of family-owned businesses in Nakuru East Sub County. The study collected data through the use of closed-ended questionnaires. The piloting of the research instrument was carried out in Eldoret town. Eldorettown bears also most similar characteristics with Nakuru East Sub County in terms of growth and population.To ascertain the validity of the research instruments the study used content validity index. This was determined by the use of subject matter experts who included the research supervisor and four managers of the family owned businesses. To establish the reliability of the research instruments, the study used Cronbach's Alpha test of internal consistent. The study used a Cronbach's Alpha coefficient of at least 0.7 as recommended by Mugenda (2003). The study sought all relevant permissions and authorization before the collection of data. First, the researcher sought permission to collect data from institute of post graduate studies of Kabarak University through an introduction letter. Upon receiving the introduction letter, the researcher applied for authorization for data collection from the National Commission of Science, Technology and Innovation (NACOSTI). Upon receiving the authorization, the researcher visited the selected businesses for introduction and data collection. The researcher distributed the informed statement before issuance of the questionnaires which advised the respondents on the purpose of the data collection and how the collected data was to be used.The study used the Drop Off and Pick Up later self-administration of the questionnaires in order to enhance the response rate of the respondents. Descriptive statistics was used in the study include frequencies, percentages, mean scores and standard deviation (Glăveanu, 2012). Inferential statistics was used to describe the relations and association that exists between the study variables. In respect to this, the study used multiple linear regression to test the relationship between each independent variable with the dependent variable for testing the hypotheses of the study. This was tested at 5\% significant level. The entire data analysis was presented in terms of tables due to the ease of using tabular presentation of statistical results.

\section{RESULTS}

\section{A. Response Rate}

The study issued 96 questionnaires to the respondents in which 84 questionnaires were returned. This made a response rate of $87.5 \%$. This response was considered sufficient for the study as it was above the recommended minimum of $80 \%$.

\section{Distribution by Age}

\begin{tabular}{ccc}
\hline Age & Frequency & Percentages \\
\hline 20 Years and & 4 & $4.7 \%$ \\
Below & & \\
21-30 Years & 6 & $7.1 \%$ \\
31-40 Years & 10 & $11.9 \%$ \\
41-50 Years & 29 & $34.5 \%$ \\
Above 50 Years & 35 & $41.8 \%$ \\
\hline Total & $\mathbf{8 4}$ & $\mathbf{1 0 0 \%}$ \\
\hline
\end{tabular}

The study examined on the age distribution of the respondents in which $4.7 \%$ of the respondents 20 years and below, $7.1 \%$ were between $21-30$ years, $31-40$ years stood at $11.9 \%, 41-50$ years stood at $34.5 \%$, and $41.8 \%$ were above 50 years of age. The study results thus indicated that a majority of the respondents were old at above 41 years of age 
Distribution by Level of Education

\begin{tabular}{lcc}
\hline & Frequency & Percentage \\
\hline Certificate & 16 & $19.0 \%$ \\
Diploma & 39 & $46.4 \%$ \\
Degree & 20 & $23.8 \%$ \\
Post Graduate & 9 & $10.8 \%$ \\
\hline Total & $\mathbf{8 4}$ & $\mathbf{1 0 0 \%}$ \\
\hline
\end{tabular}

The study noted that $19.0 \%$ of the respondents had certificate level of education while $46.4 \%$ of the respondents had diploma level of education. On the other hand, $23.8 \%$ and $10.8 \%$ of the respondents indicated that they had degree and post graduate degrees respectively.

Descriptive Statistics for Organizational Culture

\begin{tabular}{|c|c|c|c|c|c|c|c|}
\hline & \multirow{2}{*}{$\begin{array}{c}\text { NE } \\
\text { Freq } \\
\%\end{array}$} & \multirow{2}{*}{$\begin{array}{c}\text { SE } \\
\text { Freq } \\
\%\end{array}$} & \multirow{2}{*}{$\begin{array}{c}\text { ME } \\
\text { Freq } \\
\%\end{array}$} & \multirow{2}{*}{$\begin{array}{c}\text { LE } \\
\text { Freq } \\
\%\end{array}$} & \multirow{2}{*}{$\begin{array}{c}\text { VLE } \\
\text { Freq } \\
\%\end{array}$} & \multicolumn{2}{|c|}{ Chi-Square } \\
\hline & & & & & & $\chi^{2}$ & $\mathbf{P}$ \\
\hline Hierarchy Culture & $\begin{array}{c}3 \\
3.6 \%\end{array}$ & $\begin{array}{c}11 \\
13.1 \%\end{array}$ & $\begin{array}{c}17 \\
20.2 \%\end{array}$ & $\begin{array}{c}39 \\
46.4 \%\end{array}$ & $\begin{array}{c}14 \\
16.7 \%\end{array}$ & 15.877 & 0.044 \\
\hline Market Culture & $\begin{array}{c}2 \\
2.4 \%\end{array}$ & $\begin{array}{c}8 \\
9.5 \%\end{array}$ & $\begin{array}{c}11 \\
13.1 \%\end{array}$ & $\begin{array}{c}51 \\
60.7 \%\end{array}$ & $\begin{array}{c}12 \\
14.3 \%\end{array}$ & 15.125 & 0.057 \\
\hline Entrepreneurial Culture & $\begin{array}{c}5 \\
6.0 \%\end{array}$ & $\begin{array}{c}3 \\
3.6 \%\end{array}$ & $\begin{array}{c}10 \\
11.9 \%\end{array}$ & $\begin{array}{c}53 \\
63.1 \%\end{array}$ & $\begin{array}{c}13 \\
15.5 \%\end{array}$ & 16.793 & 0.032 \\
\hline Consensual Culture & $\begin{array}{c}6 \\
7.1 \%\end{array}$ & $\begin{array}{c}4 \\
4.8 \%\end{array}$ & $\begin{array}{c}6 \\
7.1 \%\end{array}$ & $\begin{array}{c}48 \\
57.1 \%\end{array}$ & $\begin{array}{c}20 \\
23.8 \%\end{array}$ & 17.324 & 0.027 \\
\hline Competitive Culture & $\begin{array}{c}4 \\
4.8 \% \\
\end{array}$ & $\begin{array}{c}6 \\
7.1 \%\end{array}$ & $\begin{array}{c}12 \\
14.3 \% \\
\end{array}$ & $\begin{array}{c}47 \\
56.0 \% \\
\end{array}$ & $\begin{array}{c}15 \\
17.9 \% \\
\end{array}$ & 19.117 & 0.014 \\
\hline
\end{tabular}

The respondents were asked on the manner in which very large extent respectively. The metric was also examined the hierarchy culture influenced the business performance. In the context of this indicator $3.6 \%$ of the respondents indicated that it influenced the business performance to no extent. A majority of the respondents noted that hierarchical culture influenced the business performance to a large extent at $46.4 \%$ of the respondents with a further $16.7 \%$ of the respondents indicating to a very large extent. The chi square test of independence was used to examine on whether the hierarchical culture had a statistically significant association with the business performance. The study achieved chi square results of 15.877 with a $p$ value of 0.044 . The chi square results thus indicated that the hierarchical culture had a statistically significant association with business performance at $5 \%$ level of significance since $p$ value is less than 0.05 .

The extent in which the market culture influenced the business performance was examined. The study found that a cumulative percentage of $75 \%$ of the respondents agreed that the metric had an influence on the business performance to a large extent. This is compared to $2.4 \%$, $9.5 \%$, and $13.1 \%$ of the respondents who indicated to no extent, small extent and moderate extent respectively. The results of this study in respect to the market culture are similar to those by Sadighi (2017) in the United Kingdom, investigated the role of organizational culture on the performance of Small and Medium-Sized Enterprises (SMEs) in the health sector. The study had found that market culture had the highest influence on organizational performance. In line to this finding, Larentis, Simone, and Antonio (2017) indicated that market culture was a significant predictor of organizational performance in organizations in Brazil.

The extent in which the entrepreneurial culture influenced business performance was examined with $6.0 \%, 3.6 \%$, $11.9 \%, 63.1 \%$, and $15.5 \%$ of the respondents indicating to a no extent, small extent, moderate extent, large extent and on whether it had a statistically significant association with the business performance. In this context, the study achieved chi square value of 16.793 with a $p$ value of 0.032 . This indicated that the entrepreneurial culture had a statistically significant association with business performance at $5 \%$ level of significance. The results of the current study are similar to those in other empirical studies. Tubey, Rotich,and Kurgat (2015) found out that organizational culture among businesses owned by female in Nairobi County influenced the level of performance of an organization. In respect to this entrepreneurial culture, willingness to take businesses risks, emphasis on competitive actions, readiness to meet new challenges, procedural coordination of activities and having common interest towards the organizational goals influenced the level of performance of female owed enterprises.

The extent in which the consensual culture influenced business performance had a majority of the respondents $57.1 \%$ being in agreement that the measure influenced business performance to a large extent. This is compared to $23.8 \%$ of the respondents who indicated that it influenced the business performance to a very large extent. The study further used the chi square in examination of the whether the consensual culture had a statistically significant association with the business performance. The study achieved a chi square of 17.324 with a $\mathrm{p}$ value of 0.027 . This led to the conclusion that consensual culture had a statistically significant association with the business performance aspects. The results of the current study is similar to those of other studies. In Indonesian context, Sengke (2016) carried out a study that sought to investigate the influence of organizational culture on the performance of businesses. Sengke (2016) found that consensual culture had the greatest influence while entrepreneurial culture had the least influence and therefore the recommendation to encourage employees to 
be more innovative within their roles.

The influence of the competitive culture was examined. In this context, a majority of $56.0 \%$ of the respondents indicated that the competitive culture had an influence on the business performance to a large extent. A further $17.9 \%$ of the respondents indicated that the competitive culture had an influence on the business performance to a very large extent. The chi square test of independence was used to examine on whether competitive culture had statistically significant association with business performance. The study in this regard achieved chi square value of 19.117 with a $p$ value of 0.014 . This led to the conclusion that there was a statistically significant association between competitive culture and

\begin{tabular}{|c|c|c|c|c|c|c|c|}
\hline & \multirow{2}{*}{$\begin{array}{c}\text { NE } \\
\text { Freq } \\
\%\end{array}$} & \multirow{2}{*}{$\begin{array}{c}\text { SE } \\
\text { Freq } \\
\%\end{array}$} & \multirow{2}{*}{$\begin{array}{c}\text { ME } \\
\text { Freq } \\
\%\end{array}$} & \multirow{2}{*}{$\begin{array}{c}\text { LE } \\
\text { Freq } \\
\%\end{array}$} & \multirow{2}{*}{$\begin{array}{c}\text { VLE } \\
\text { Freq } \\
\%\end{array}$} & \multicolumn{2}{|c|}{ Chi-Square } \\
\hline & & & & & & $\chi^{2}$ & P Value \\
\hline Board Size & $\begin{array}{c}5 \\
6.0 \%\end{array}$ & $\begin{array}{c}2 \\
2.4 \%\end{array}$ & $\begin{array}{c}10 \\
11.9 \%\end{array}$ & $\begin{array}{c}51 \\
60.7 \%\end{array}$ & $\begin{array}{c}16 \\
19.0 \%\end{array}$ & 14.332 & 0.072 \\
\hline Board Independence & $\begin{array}{c}6 \\
7.1 \%\end{array}$ & $\begin{array}{c}4 \\
4.8 \%\end{array}$ & $\begin{array}{c}7 \\
8.3 \%\end{array}$ & $\begin{array}{c}53 \\
63.1 \%\end{array}$ & $\begin{array}{c}14 \\
16.7 \%\end{array}$ & 38.008 & 0.000 \\
\hline Audit Committee Size & $\begin{array}{c}5 \\
6.0 \%\end{array}$ & $\begin{array}{c}10 \\
11.9 \%\end{array}$ & $\begin{array}{c}5 \\
6.0 \%\end{array}$ & $\begin{array}{c}48 \\
57.1 \%\end{array}$ & $\begin{array}{c}16 \\
19.0 \%\end{array}$ & 15.569 & 0.049 \\
\hline Board Competencies & $\begin{array}{c}4 \\
4.8 \%\end{array}$ & $\begin{array}{c}6 \\
7.1 \%\end{array}$ & $\begin{array}{c}11 \\
13.1 \%\end{array}$ & $\begin{array}{c}55 \\
65.5 \%\end{array}$ & $\begin{array}{c}8 \\
9.5 \%\end{array}$ & 32.250 & 0.000 \\
\hline Institutional Ownership & $\begin{array}{c}7 \\
8.3 \%\end{array}$ & $\begin{array}{c}14 \\
16.7 \%\end{array}$ & $\begin{array}{c}16 \\
19.0 \%\end{array}$ & $\begin{array}{c}35 \\
41.7 \%\end{array}$ & $\begin{array}{c}12 \\
14.3 \%\end{array}$ & 19.289 & 0.013 \\
\hline
\end{tabular}

The extent in which the board size influenced the business performance was examined with the results indicating that a majority of $60.7 \%$ of the respondents agreed with the metric to a large extent. A further $19.0 \%$ of the respondents indicated that the influence was to a very large extent making cumulatively $79.7 \%$ of the respondents indicating that board size influenced business performance to a large extent. The study further sought to examine on whether the board size had a statistically significant association with business performance at 5\% level of significance. The study found that board size achieved a chi square value of 14.332 with a p value of 0.072 indicating that there was no statistically significant association between board size and business performance. The results of this current study are in tandem with that of Homaidi, Almaqtari and Ahmad (2019) who carried out a study that sought to establish the influence of corporate governance on the financial performance of hotels in India. Using regression analysis, the study established that there was a significant impact on financial performance of hotels due to corporate governance mechanism such as board size, audit committee size, board competencies, and institutional ownership. These results are comparable to the findings of (Kulathunga, Weerasinghe, \& Jayarathne, 2017)corporate governance mechanism used has significant impact of the financial performance of large corporation in the two countries. It was revealed in this respect that good corporate governance increased the returns of the organizations under investigation.

The study further examined the influence of board independence on the business performance aspects. The study business performance aspects at $5 \%$ level of significance. The findings of the current study correlate with those other studies examining the same phenomenon. In Rwandan context, Ndemezo and Kayitana (2018), found out that family businesses were competitive compared to non-family SMEs due to formulation of long-term policies and motivation of employees to bear the vision of the family businesses. Ndemezo and Kayitana (2018)further established that family businesses implemented cost saving strategies and this help such businesses to gain competitive advantage in the Rwanda market. found that $7.1 \%, 4.8 \%, 8.3 \%, 63.1 \%$ and $16.7 \%$ of the respondents indicated that the board independence influenced business performance aspects. The study further sought to examine on whether the board independence had a statistically significant association with business performance. The study achieved a chi square value of 38.008 with a $\mathrm{p}$ value of 0.000 . This indicated that there was a statistically significant association between board independence and business performance aspects. The extent in which the audit committee size influenced the business performance was examined. In this context a cumulative percentage of $76.1 \%$ of the respondents indicated that the audit committee size influence business performance to a large extent.

The study further noted that $6.0 \%, 11.9 \%$ and $6.0 \%$ of the respondents indicated that the audit committee size influenced the business performance to no extent, small extent and moderate extent respectively. The influence of the board competencies on the business performance was examined with a majority of the respondents at $65.5 \%$ indicating that it influenced business performance to large extent. It was only a small percentage of $4.8 \%$ of the respondent who indicated that the business competences didn't influence the business performance to any extent. The chi square test of association between board competencies and business performance achieved a chi square value of 32.250 with a $p$ value of 0.000 . This indicated that there was a statistically significant association between board competencies and business performance of the family businesses. The study findings are similar to those of Naimah and Hamidah (2017) who established that there was 
significant relationship between the corporate governance and financial performance of the businesses. Using regression analysis, it was established that board size and board independence, audit committee meeting, audit committee size, outside directors and corporate governance perception index significantly predicted the financial performance of businesses in Indonesia.

The extent in which the institutional ownership influenced business performance of the family business was examined. The study found that $8.3 \%$ of the respondents Performance of Family Owned Businesses indicated that it influenced the business performance to no extent. This is compared to $16.7 \%, 19.0 \%, 41.7 \%$, and $14.3 \%$ of the respondents who indicated that institutional ownership influenced business performance to small extent, moderate extent, large extent and very large extent respectively. The chi square test of independence was examined with the achieved chi square being 19.289 with a $p$ value of 0.013 . This thus led to the conclusion that there was a statistically significant association between institutional ownership and business performance of the family businesses at $5 \%$. This was due to a $\mathrm{p}$ value of less than 0.05 .

\begin{tabular}{|c|c|c|c|c|c|}
\hline & $\begin{array}{l}\text { NE } \\
\text { Freq } \\
\%\end{array}$ & $\begin{array}{l}\text { SE } \\
\text { Freq } \\
\%\end{array}$ & $\begin{array}{l}\text { ME } \\
\text { Freq } \\
\%\end{array}$ & $\begin{array}{l}\text { LE } \\
\text { Freq } \\
\%\end{array}$ & $\begin{array}{l}\text { VLE } \\
\text { Freq } \\
\%\end{array}$ \\
\hline \multirow{2}{*}{ Customers are satisfied } & 3 & 4 & 12 & 41 & 24 \\
\hline & $3.6 \%$ & $4.8 \%$ & $14.3 \%$ & $48.8 \%$ & $28.6 \%$ \\
\hline \multirow{2}{*}{ There is high return on assets } & 2 & 6 & 7 & 43 & 26 \\
\hline & $2.4 \%$ & $7.1 \%$ & $8.3 \%$ & $51.2 \%$ & $31.0 \%$ \\
\hline \multirow{2}{*}{ The businesses has high market share } & 4 & 7 & 11 & 42 & 20 \\
\hline & $4.8 \%$ & $8.3 \%$ & $13.1 \%$ & $50.0 \%$ & $23.8 \%$ \\
\hline \multirow{2}{*}{ There is high sales volumes } & 5 & 4 & 16 & 37 & 22 \\
\hline & $6.0 \%$ & $4.8 \%$ & $19.0 \%$ & $44.0 \%$ & $26.2 \%$ \\
\hline \multirow{2}{*}{ There is high return on investment } & 2 & 9 & 14 & 40 & 19 \\
\hline & $2.4 \%$ & $10.7 \%$ & $16.7 \%$ & $47.6 \%$ & $22.6 \%$ \\
\hline
\end{tabular}

The question as to influence of the strategic leadership on the performance of family owned businesses had $3.6 \%, 4.8 \%$, $14.3 \%, 48.8 \%$, and $28.6 \%$ of the respondents indicating to no extent, small extent, moderate extent, large extent and very large extent respectively. The study thus noted that a cumulative percentage of $77.4 \%$ of the respondents noted that strategic leadership influenced on the performance of the family business to a large extent. It was only $3.6 \%$ of the respondents indicated that strategic leadership influenced customer satisfaction to no extent.

In respect to the extent in which strategic leadership influenced high returns on assets, a cumulative percentage of Correlational Analysis
$82.2 \%$ of the respondents indicated to a large extent. This is compared to $2.4 \%, 7.1 \%$, and $8.3 \%$ of the respondents who indicated to a no extent, small extent and moderate extent respectively. The influence of strategic leadership on the high sales volumes had $6.0 \%, 4.8 \%, 19.0 \%, 44.0 \%$, and $26.2 \%$ of the respondents indicating to a no extent, small extent, moderate extent, large extent and very large extent respectively. Finally, the influence of strategic leadership on the high return on investment had $2.4 \%, 10.7 \%, 16.7 \%$, $47.6 \%$, and $22.6 \%$ of the respondents indicating to no extent, small extent, moderate extent, large extent and very large extent respectively.

\begin{tabular}{llccc}
\hline & & $\begin{array}{c}\text { Organizational } \\
\text { Culture }\end{array}$ & $\begin{array}{c}\text { Corporate } \\
\text { Governance }\end{array}$ & $\begin{array}{c}\text { Business } \\
\text { Performance }\end{array}$ \\
\hline Organizational & Pearson Correlation & 1 & $.322^{* *}$ & $.639^{* *}$ \\
Culture & Sig. (2-tailed) & & .003 & .000 \\
& $\mathrm{~N}$ & & 84 & 84 \\
& Pearson Correlation & & 1 & $.723^{* *}$ \\
Corporate & Sig. (2-tailed) & $\mathrm{N}$ & .000 & 84 \\
Governance & Sig. (2-tailed) & & & .000 \\
& $\mathrm{~N}$ & & 84 & .000 \\
& Sig. (2-tailed) & & & 84 \\
Business & $\mathrm{N}$ & & & 1 \\
Performance & Pearson Correlation & Sig. (2-tailed) & $\mathrm{n}$ & 84 \\
\hline
\end{tabular}

The Pearson correlation coefficients were used in examining the correlation relationship between the individual independent variable and the dependent variable. The organizational culture had a positive correlation of 0.639 with business performance. The study further found that the observed relationship was statistically significant in nature at $5 \%$ level of significance due to a $\mathrm{p}$ value of less than 0.05 . The study further examined on whether corporate governance had a correlation relationship with business performance. The study found that there was a correlational coefficient of 0.723 between corporate governance and business performance. 
This was deemed to be statistically significant at $5 \%(0.05)$

level of significance due to an achieved p value of 0.000 .

Multiple Linear RegressionAnalysis

\begin{tabular}{|c|c|c|c|c|c|c|}
\hline \multicolumn{2}{|r|}{ Model } & \multicolumn{2}{|c|}{ Unstandardized Coefficients } & \multirow{2}{*}{$\begin{array}{c}\text { Standardized } \\
\text { Coefficients } \\
\text { Beta }\end{array}$} & \multirow[t]{2}{*}{$\mathrm{t}$} & \multirow[t]{2}{*}{ Sig. } \\
\hline & & B & Std. Error & & & \\
\hline & (Constant) & .386 & .172 & & 2.243 & .028 \\
\hline \multirow[t]{2}{*}{1} & Organizational Culture & .260 & .034 & .384 & 7.724 & .000 \\
\hline & Corporate Governance & .215 & .038 & .308 & 5.611 & .000 \\
\hline
\end{tabular}

a. Dependent Variable: Business Performance

The regression coefficient was examined in order to understand the influence of a unit increase in the dependent variable as a result of the unit change in the independent variable. The achieved relationship was further examined on whether it would hold in the population (statistical significance) at $5 \%$ level of significance. In respect to the role of organizational culture on the business performance, the achieved regression coefficient was 0.260 with t test statistic value of 7.724 and a $p$ value of 0.000 . This indicated that a unit increase in organizational culture would lead to 0.260 increases in business performance with the other variables kept constant. These results were found statistically significant since $\mathrm{p}$ value was 0.000 and was less than the 0.05 level of significance. This led to the rejection of the following hypothesis (H01) and acceptance of the alternative hypothesis.

H01: Organizational culture has no significant statistical influence on the performance of family owned businesses in Nakuru East Sub County, Kenya.

In respect to the role of corporate governance on the business performance, the achieved regression coefficient was 0.215 with $t$ test statistic value of 5.611 and a $p$ value of 0.000 . This indicated that a unit increase in corporate governance would lead to 0.215 increases in business performance with the other variables kept constant. These results were found statistically significant since $\mathrm{p}$ value was 0.000 and was less than the 0.05 level of significance. This led to the rejection of the following hypothesis (H02) and acceptance of the alternative hypothesis.

H02: Corporate governance has no significant statistical influence on the performance of family owned businesses in Nakuru East Sub County, Kenya.

\section{CONCLUSION \& RECOMMENDATION}

\section{A. Conclusion}

The study found that the two independent variables that is corporate governance, and organizational culture cumulatively attributed to a huge variance of business performance. The specific variables influences on the dependent variables were examined in order to make conclusion at individual variable level. The conclusions of the study were made on the relationship between the specific independent variables and the dependent variables. The organizational culture had a statistically significant positive correlation with business performance. In respect to the role of organizational culture on the business performance, the achieved regression coefficient was 0.260 indicating that a unit increase in organizational culture would lead to 0.260 increase in business performance with the other variables kept constant. The results were statistically significant at $5 \%$ level of significance indicating that leading to the rejection of the null hypothesis that organizational culture had no significant influence on the performance of family owned businesses in Nakuru East Sub County, Kenya. The alternative hypothesis that there was a statistically significant influence on the performance of the family owned businesses in Nakuru East Sub County was accepted. In respect to the relationship between corporate governance and business performance, the study found that there was a statistically significant positive correlational relationship between corporate governance and business performance. The study further found that a unit increase in corporate governance would lead to 0.215 increase in business performance with the other variables kept constant. These results were found statistically significant since $\mathrm{p}$ value was 0.000 and was less than the 0.05 level of significance. The study thus concluded that there was a statistically significant influence on the performance of family owned businesses in Nakuru East Sub County, Kenya

\section{B. Recommendation}

The study recommended that the organizational culture, corporate governanceshould be emphasized and practiced within the family businesses. This was informed by these aspects being significant predictors of the organizational performance of the family owned businesses.

\section{REFERENCES}

[1] Agbim, K. C., \& Ph, D. (2018). Business Network Effect on the Institutionalization of Family Businesses in South Eastern Nigeria. Open Journal of Economics and Commerce, 1(1), 1-10.

[2] Aliyu, M. S., \& Rosli, M. (2014). Determining the effects of organizational culture on small and medium enterprises performance: A SEM Approach. Journal of Economics and Sustainable Development, 5(17), 1-9.

[3] Bannò, M., \& Sgobbi, F. (2016). Family Business Characteristics and the Approach to HRM in Overseas Ventures. Journal of Small Business Management, 54(2), 640-658.

[4] Bizri, R. (2016). Succession in the family business: drivers and pathways. International Journal of Entrepreneurial Behaviour and Research, 22(1), 133-154.

[5] Emeagwal, L., \& Ogbonmwan, K. O. (2018). Mapping the perceived role of strategic human resource management practices in sustainable competitive advantage. Academy of Strategic Management Journal, $17(2), 1-19$.

[6] Glăveanu, V. (2012). Handbook of Research Methods in Industrial and Organizational Psychology. New Jersey: Taylor \& Francis.

[7] Homaidi, E. A. Al, Almaqtari, F. A., \& Ahmad, A. (2019). Impact of Corporate Governance Mechanisms on Financial Performance of Hotel Companies: Empirical Evidence from India. Managerial Auditing Journal, 8(2), 1-21. 
[8] Kulathunga, K. M. K. N. ., Weerasinghe, W. D. J. ., \& Jayarathne, J. A. . (2017). Corporate Governance and Dividend Policy: A Study of Listed Manufacturing Companies in Sri Lanka. International Journal of Scientific Research and Innovative Technology, 4(2), 98-114.

[9] Larentis, F., Simone Antonello, C., \& Antonio Slongo, L. (2017). Organizational culture and relationship marketing: an interorganizational perspective. Review of Business Management, 20(1), 37-56.

[10] Latif, K. F. (2016). An Empirical Investigation into the relationship between Organizational Culture, Internal Service Quality (ISQ) and Organizational Performance. Abasyn Journal of Social Sciences -, 9(1), 31-53.

[11] Leithy, W. El. (2017). Organizational Culture and Organizational Performance. International Journal of Economics \& Management Sciences, 06(04), 16-21.

[12] Li, Y., Armstrong, A., \& Clarke, A. (2014). Relationships of Corporate Governance Mechanisms and Financial Performance in Islamic Banks: a Meta-analysis. Journal of Law and Governance, 9(1), 50-63.

[13] M'Ithiria, E. N., \& Musyoki, D. (2014). Corporate Governance , Ownership Structure Perspective and Firm Value : Theory, and Survey of Evidence. International Journal of Research in Management \& Business Studies - IIRMBS, 1(3), 57-61.

[14] Naimah, Z., \& Hamidah. (2017). The Role of Corporate Governance in Firm Performance. SHS Web of Conferences, 34(4), 1-6.

[15] Ndemezo, E., \& Kayitana, C. (2018). Corporate Governance, Corporate Entrepreneurship and Firm Performance: Evidence from the Rwandese Manufacturing Industry. Indian Journal of Corporate Governance, 11(2), 103-121.

[16] Nicholson, H. (2011). Research Methods in Theatre and Performance. Research Methods for the Arts and the Humanities, 3(4), 1-33.

[17] Palladan, A. A., Abdulkadir, K. B., \& Chong, Y. W. (2016). The Effect of Strategic Leadership, Organization Innovativeness, Information Technology Capability on Effective Strategy Implementation: A Study of Tertiary Institutions in Nigeria. IOSR Journal of Business and Management, 18(9), 109-115.

[18] Saad, G. Ben, \& Abbas, M. (2018). The impact of organizational culture on job performance: A study of Saudi Arabian public sector work culture. Problems and Perspectives in Management, 16(3), 207-218.

[19] Sadighi, S. (2017). Anglia Ruskin University Organizational Culture and Performance: Research on SMEs at Tele-Healthcare Industry, United Kingdom. International Entrepreneurship and Management Journal, 6(3), 1-14.

[20] Sengke, G. (2016). the Effect of Organizational Culture Towards Organizational Performance Case Study: Dinas Perindustrian Dan Perdagangan Provinsi Sulawesi Utara. Jurnal Berkala Ilmiah Efisiensi, 3(4), 567-575.

[21] Tubey, R., Rotich, K. J., \& Kurgat, A. (2015). History , Evolution and Development of Human Resource Management: A Contemporary Perspective. European Journal of Business and Management, 7(9), 139-149.

[22] Xi, J. (Melanie), Kraus, S., Filser, M., \& Kellermanns, F. W. (2013). Mapping the field of family business research: past trends and future directions. International Entrepreneurship and Management Journal, 11(1), 113-132. 